\title{
A mini review on corrosion, inhibitors and mechanism types of mild steel inhibition in an acidic environment
}

\section{A. Kadhim, ${ }^{1}$ N. Betti, ${ }^{2}$ H.A. Al-Bahrani, ${ }^{3}$ M.K.S. Al-Ghezi, ${ }^{4}$ T. Gaaz, ${ }^{5}$ A.H. Kadhum ${ }^{3}$ and A. Alamiery ${ }^{4,6}$ (iD}

${ }^{1}$ Laser and Optoelectronics Engineering Department, University of Technology, 10001, Baghdad, Iraq

${ }^{2}$ Materials Engineering Department, University of Technology, P.O. Box: 1001, Baghdad, Iraq

${ }^{3}$ Al-Ameed University, P.O. Box: 1238, Karbalaa, Iraq

${ }^{4}$ Energy and Renewable Energies Technology Center, University of Technology, 10001, Baghdad, Iraq

${ }^{5}$ Technical College Al-Musaib, Al-Furat Al-Awsat Technical University, Al-Musaib, 51006, Babil, Iraq

${ }^{6}$ Department of Chemical and Process Engineering, Faculty of Engineering and Built Environment, University Kebangsaan Malaysia (UKM), P.O. Box: 43000, Bangi, Selangor, Malaysia

*E-mail: dr.ahmed1975@ukm.edu.my

\section{Abstract}

For a long period, there have been significant losses at high costs due to the corrosion and damage it causes in most industrial processes, especially in the oil and gas industries. Consequently, erosion represents a serious threat to humans and animals, as it has a catastrophic impact on the environment, which calls for permanent and final solutions to it, and therefore there is a lot of literature related to the issue of corrosion. Hence the importance of natural or synthetic organic corrosion inhibitors, as they are usually inexpensive and harmless because they biodegrade, as proven by previous studies. Organic molecules that contain a number of heterogeneous atoms and double and triple bonds in their molecular structures have a great ability to resist corrosion of metals in various corrosive solutions. Much research has been reported annually by many researchers related to corrosion inhibitors and their preparation or extraction as well as the mechanism of classification and inhibition. The current study represents the types of corrosion, types of inhibitors, mechanisms of action, measuring the corrosion inhibitor efficiency and a brief presentation of research articles that use manufactured or extracted coumarins as corrosion inhibitors, and a comparison between them in terms of inhibition effectiveness has also been made.

Received: March 30, 2021. Published: July 6, 2021

doi: $\underline{10.17675 / 2305-6894-2021-10-3-2}$

Keywords: corrosion types, mechanism, corrosion inhibitor, inhibition efficiency. 


\section{Introduction}

Corrosion is metal dissolution caused by interaction with acidic corrosive environments [1] by direct chemical reactions resulting from the formation of noble compounds [2]. As described by the International Union of Pure and Applied Chemistry, corrosion is the irreversible reaction of an interlayer (polymer, metal, concrete, wood, or ceramic) with the environment leading to ingestion or dissolution of the environmental component material [3]. Corrosion is an environmental hazard with economic, preservation and safety consequences in many areas such as manufacturing, chemicals, automobiles, mechatronics, metallurgy, and medical applications [4]. Different forms of material degradation have been addressed in different environments [5]. There is also a need to create new approaches and methods to counter these hazardous phenomena from the known factors, such as coatings, defensive bushings, cathodic/anodic protection, and sealants. However, the results of studies conducted on anti-corrosion textile applications in the above engineering fields showed the use of corrosion inhibitors to be the most gentle and easy way to prevent the degradation of metals and alloys in corrosive media [6,7]. The corrosion inhibition efficiency of untested organic corrosion inhibitors has been linked to the availability of nitrogen, oxygen, phosphorous and sulfur atoms in organic compounds [8] that have both protective effects and corrosion inhibiting potential. The high-ranking corrosion inhibitors were cited to be green oxygen corrosion inhibitors that display their inhibitory effect via hydrolysis or chemical absorption at the mineral solution interface by removing surface water molecules to form a dense barrier film $[9,10]$. The incidence of a coordinate covalent bond is subject to the interaction between the lone pair and the electrons available in untested organic corrosion inhibitor molecules with vacant steel orbitals [11]. However, the combined adsorption on the metal surface using the pi-bond formation is outperformed as a final result of the interference of the p electron with the three-dimensional vacant orbital of the iron atom [12] due to the availability of $\mathrm{N}, \mathrm{O}$, and $\mathrm{S}$ atoms and the double bonds in an organic compound [13]. The aim of this study is to discuss in brief the types of corrosion, types of inhibitors, and mechanisms of action of inhibitor molecules to control or impede the corrosion of mild steel in corrosive environments.

\section{Types of corrosion}

Corrosion is defined as the deterioration of a substance or its characteristics due to interactions with a corrosive medium [14]. The tendency of a metal to corrode depends on its grain structure, composition formed upon alloying, or the temperature of a metal surface developed upon deformation during fabrication. Corrosion prevention would be more practical than trying to eliminate it completely. Given that the environment plays as significant part in corrosion, the mechanisms of corrosion can be as varied as the medium to which a material is exposed and thus may be complex to understand. Parameters that produce corrosion include metal reactivity, impurities, air, moisture, $\mathrm{SO}_{2}$ and $\mathrm{CO}_{2}$ in addition to electrolytes. Corrosion prevention and retardation are aimed at addressing these factors [15]. The various kinds of corrosion which depend on the media surrounding the material are displayed in Table 1 [16]. 
Table 1. The description of corrosion types.

\begin{tabular}{|c|c|}
\hline $\begin{array}{l}\text { Type of } \\
\text { corrosion }\end{array}$ & Description \\
\hline $\begin{array}{l}\text { Uniform } \\
\text { corrosion }\end{array}$ & $\begin{array}{c}\text { A corrosive attack that occurs continuously over the entire surface or a significant } \\
\text { percentage of the overall area is described as uniform corrosion. Examples of surface } \\
\text { corrosion include dulling of a superficial or polished surface and acid cleaners or } \\
\text { oxidation of steel (discoloration). }\end{array}$ \\
\hline $\begin{array}{l}\text { Galvanic } \\
\text { corrosion }\end{array}$ & $\begin{array}{l}\text { Bimetallic corrosion is also known as an electrochemical phase in which a metal } \\
\text { corrodes over another metal with which it comes into contact in the presence of an } \\
\text { electrolyte. When two separate metals are dipped in a conductive solution and } \\
\text { electrically connected, galvanic corrosion occurs. }\end{array}$ \\
\hline $\begin{array}{l}\text { Pitting } \\
\text { corrosion }\end{array}$ & $\begin{array}{l}\text { A localized type of corrosion that creates cavities or "holes" in a substance. Pitting is } \\
\text { known as more risky than uniform corrosion damage because the identification, } \\
\text { estimation and configuration of it is tougher. The pit is also filled by corrosion products. }\end{array}$ \\
\hline $\begin{array}{l}\text { Stress } \\
\text { corrosion } \\
\text { cracking }\end{array}$ & $\begin{array}{l}\text { The growth of a crack formed in a corrosive setting is referred to as stress corrosion } \\
\text { cracking (SCC). It can result in an unforeseen and unexpected failure of metal alloys } \\
\text { that are normally ductile under tensile stress, especially at high temperatures. SCC is } \\
\text { very solvent-specific and certain alloys can be subject to SCC only if subjected to a } \\
\text { limited number of chemical conditions. The chemical environment that causes SCC for } \\
\text { a particular alloy is often the one that causes mild corrosion to the metal. }\end{array}$ \\
\hline $\begin{array}{l}\text { Corrosion } \\
\text { fatigue }\end{array}$ & $\begin{array}{c}\text { It occurs in a corrosive fatigue environment. It is the mechanical weakening of a } \\
\text { material under corrosion and cyclical loading operating jointly. Almost all engineering } \\
\text { systems undergo some form of alternate stress and are subjected to hazardous } \\
\text { conditions throughout their lifespan. }\end{array}$ \\
\hline $\begin{array}{l}\text { Intergranular } \\
\text { corrosion }\end{array}$ & $\begin{array}{l}\text { IGC, also known as intergranular attack (IGA), is a type of corrosion in which the } \\
\text { boundaries of crystalline materials are more susceptible to erosion than the interiors. }\end{array}$ \\
\hline $\begin{array}{l}\text { Crevice } \\
\text { corrosion }\end{array}$ & $\begin{array}{c}\text { Refers to a localized attack on a surface of metal at a distance of a fracture between two } \\
\text { joining plates, or directly adjacent to it. Between two metals or one metal and non- } \\
\text { metallic material the gap or crevice may be formed. Both metals are corrosion resistant } \\
\text { outside the gap or without the gap. }\end{array}$ \\
\hline
\end{tabular}

It is a particular type of corrosion which occurs in the form of randomly dispersed Filiform filaments under some thin coatings. Corrosion of filiforms is often referred to as corrosion "underfilm corrosion". Filiform corrosion is observed on surfaces of painted steel, magnesium, and aluminum with thin layers of tin, silver, gold, phosphate, enamel and varnish.

Erosion corrosion

Material surface deterioration due to mechanical activity, often by impaction of material, slurry abrasion, particles trapped in fast-flowing liquid or gas, bubbles or droplets, cavitation...

Fretting Corrosion impact on touch surface asperities is referred to. In the presence of repetitive corrosion relative surface movement, for instance, by vibration, this harm is incurred under load. 


\section{Inhibitor types}

During the acidizing procedure a number of organic compounds serve as CIs for steels, including acetylenic alcohols, aldehyde-containing aromatic compounds, imminium salts, nitriles, triazoles, thiocyanates, pyridine and its derivatives or salts [17], quinoline derivatives, thiourea derivatives, quaternary salts, thiosemicarbazide [18, 19], quinoline derivatives, thiourea derivatives, thiosemicarbazide derivatives, nitriles, imminium-based salts, and nitrogen heterocycles. Nitrogen and acetylenic alcohol molecules appear to form a film on metal surfaces and to be able to delay the metal breakdown (anodic response) and production of hydrogen (a cathodic reaction) [20]. Propargyl alcohol is soluble in acidic liquids, however, with an ever larger length of carbon chain, the solubility of other acetylenic alcohols reduces. In conjunction with quaternary ammonium surfactants, the solubility of these acetylenic alcohols can be improved [30]. The industrial supply and cost efficiency of acetylenic alcohols was commonly used. The normal CI for acidification is generally propargyl alcohol [21], with the synergistic influence of other compounds often substantial. Propargyl alcohol, its salts, cinnamaldehyde, and aromatic compounds such as quaternary pyridinium chloride are the most widely encountered CIs in the natural resource industry. In 1984 an outline of the use of CIs for acid media was published by Schmitt [22].

\subsection{Natural corrosion inhibitors}

Natural products such as plant extracts, coumarins, amino acids, and natural polymers were published to be effective inhibitors for mild steel corrosion. Table 2 presents selected types of natural products that are used as corrosion inhibitors for mild steel in acidic media [23].

Table 2. Corrosion inhibitory characteristics of selected natural products on mild steel in corrosive environments.

\begin{tabular}{cccc}
\hline Natural products & $\begin{array}{c}\text { Corrosive } \\
\text { environment }\end{array}$ & $\boldsymbol{I E}(\boldsymbol{\%})$ & Ref. \\
\hline Tobacco leaves & Acid media & 87.5 & {$[24]$} \\
Castor seeds & Acid media & 71.0 & {$[24]$} \\
Black pepper & Acid media & 87.5 & {$[24]$} \\
Soya bean & Acid media & 65 & {$[24]$} \\
Catechu & Acid media & 50.0 & {$[24]$} \\
Papaia & Acid media & 94 & {$[25]$} \\
Poinciana pulcherrima Cassia & Acid media & 96 & {$[25]$} \\
occidentalis & Acid media & 94 & {$[25]$} \\
Datura stramonium seeds Calotropis & Acid media & 93 & {$[25]$} \\
procera & Acid media & 98 & {$[25]$} \\
\hline
\end{tabular}




\begin{tabular}{|c|c|c|c|}
\hline Natural products & $\begin{array}{c}\text { Corrosive } \\
\text { environment }\end{array}$ & $I E(\%)$ & Ref. \\
\hline Azadirachta indica & Acid media & 84 & {$[25]$} \\
\hline Auforpio turkiale sap & Acid media & 69 & {$[25]$} \\
\hline Swertia angustifolia & Acid media & $75-96$ & [26] \\
\hline A. indica & Acid media & $88-96$ & [27] \\
\hline A. indica & $\mathrm{NaCl}$ & 86.1 & [28] \\
\hline Punica granatum & $\mathrm{NaCl}$ & 79.2 & [28] \\
\hline Momordica charantia & $\mathrm{NaCl}$ & 82.4 & [28] \\
\hline Pongamia glabra, Annona squamosa & Acid media & $89-95$ & [29] \\
\hline Acacia arabica & Acid media & 93-97 & [30] \\
\hline Natural honey & $\mathrm{NaCl}$ & $82-91$ & [31] \\
\hline Mimosa tannin & Acid media & $66-87$ & {$[32]$} \\
\hline Vanillin & Acid media & $93-98$ & [33] \\
\hline $\begin{array}{c}\text { Dodecanohydrazide, cis-9-octadecanohydrazide and 10- } \\
\text { undecanohydrazide derived from fatty acids }\end{array}$ & Acid media & 85 & [34] \\
\hline $\begin{array}{l}\text { Herbs (thyme, coriander, hibiscus, anis, black cumin, and } \\
\text { garden cress) }\end{array}$ & Acid media & $37-92$ & [35] \\
\hline Allium cepa, Allium sativum, $M$. charantia & Acid media & $86-94$ & [36] \\
\hline Guar gum & Acid media & $75-93.8$ & [37] \\
\hline Zanthoxylum alatum & Acid media & $76-95$ & {$[38]$} \\
\hline Nypa fructicans & Acid media & 75.11 & [39] \\
\hline Caffeine- $\mathrm{Mn}^{2+}$ & Chloride ions & 50 & {$[40]$} \\
\hline $\begin{array}{l}\text { Eugenol from cloves } \\
\text { acetyleugeno }\end{array}$ & Acid media & $\begin{array}{l}80 \\
91\end{array}$ & [41] \\
\hline Ricinus communis leaves & $\mathrm{NaCl}$ & $43-84$ & [42] \\
\hline Berberine extracted from Coptis chinensis & Acid media & 79.7 & [43] \\
\hline Halfabar & Acid media & 90.50 & [44] \\
\hline Chamomile & Acid media & 92.97 & {$[44]$} \\
\hline Black cumin & Acid media & 88.43 & {$[44]$} \\
\hline Kidney bean & Acid media & 88.43 & [44] \\
\hline Exudate gum from Pachylobus edulis & Acid media & 56 & {$[45]$} \\
\hline Artemisia pallens & Acid media & $93-98$ & [46] \\
\hline
\end{tabular}




\begin{tabular}{cccc}
\hline Natural products & $\begin{array}{c}\text { Corrosive } \\
\text { environment }\end{array}$ & IE (\%) & Ref. \\
\hline Tridax procumbens Chromolaena odorata & Oilfield & 82.03 & {$[47]$} \\
Corchorus olitorius & environment & 95.6 & Acid media \\
\hline
\end{tabular}

Green-based inhibitors that are nontoxic in nature, such as plant extracts, are in higher demand compared to commercial inhibitors [49]. This is because plant extracts are green and sustainable materials due to their natural and biological properties and can inhibit metals and alloys from corroding [50]. The leaf, out of all parts of the plant, has the utmost preference for its abundance of phytochemicals (active components) produced through synthesis, that act similarly to commercial inhibitors. It is also vital to acknowledge that the extract of other parts of a plant such as root, bark, flower, fruit, wood, seed and peel have contributed to the inhibition efficiency [51-53]. Furthermore, phytochemical synthesis consumes carbon dioxide, which is known as the highly poisonous greenhouse gas, to use in photosynthesis, contributing to the green chemistry theory as well.

Green-based corrosion inhibitors can be divided into two classes: organic and inorganic [54-56]. The organic class of green-based corrosion inhibitors consists of synthetic substances that are nontoxic for the environment. Flavonoids, alkaloids, and byproducts of plants are examples of organic inhibitors [57]. The inorganic class of inhibitors are vastly utilized in aqueous systems due to their high productivity [58]. Chromates are toxic in nature so the employment of this inorganic inhibitor for industrial use is limited. Concerning this issue, lanthanide salts were studied as an eco-friendly inhibitor substitute [59].

Coumarins act as corrosion inhibitors due to the presence of an aromatic system and heteroatoms, that are adsorbed on mild steel surface via ion pairs of electrons on heteroatoms. This induces superior adsorption on the inhibitor molecules and excellent inhibition efficiency in decreasing the corrosion rate [60]. Physisorption and/or chemisorption are the mechanisms by which inhibitors are adsorbed on the surface of mild steel and form a protective film barrier from acidic solutions [61]. There are certain ways to protect a metal from corrosion such as coating, alloying, cathodic protection, and anodic protection. Moreover, laser treatment of metal surface has recently been used for this purpose as a way to improve the properties of metals like roughness, hardness, resistance to corrosion, etc. Corrosion inhibitors are of considerable practical importance, as they are extensively employed in reducing metal waste during production and in minimizing the risk of material failure, both of which can result in a sudden shut-down of industrial processes, which in turn leads to added costs. It is also important to use corrosion inhibitors to prevent metal dissolution and minimize acid consumption. There are two kinds of corrosion interaction according to the nature of corrosive environments: wet and dry corrosion. These types of corrosion can be classified into: general corrosion; pitting corrosion; crevice corrosion; intergranular corrosion [60-65]. Corrosion inhibitors are generally used in acid 
environments. The process of selecting an appropriate corrosion inhibitor is one of the most important issues to consider when working in an acid environment, and therefore the use of organic compounds is of great importance [66]. The efficiency of organic compounds in corrosive solutions is attributed to several factors, the most important of which are the presence of functional groups and electron pairs in the phosphorus, sulfur, oxygen and nitrogen atoms, in addition to the double and triple bonds, as well as aromatic rings. Small amounts of corrosion inhibitors have the ability to block the corrosion sites and improve the adsorption process on the mild steel surface, thus protecting the mild steel surface and increasing its life time [67]. The degree of corrosion inhibition due to absorption depends on the geometry of the particles and their size in addition to the vacuum impediment, and the thermal stability of the inhibitor molecules [68-74]. Thus, inhibitor molecules improve mild steel resistance to corrosive solutions by adsorbing on the metal surface and forming a barrier that blocks the mild steel active sites. Inhibitor adsorption on mild steel is affected by the nature of the mild steel, type of electrolyte and molecular structure of the inhibitor [75-87].

\subsection{Synthetic corrosion inhibitors}

Organic inhibitors containing heteroatoms, such as oxygen, nitrogen, and sulfur, have been confirmed experimentally and theoretically to act as efficient inhibitors in corrosive environments. $\mathrm{O}, \mathrm{N}$, and $\mathrm{S}$ are the active centers for the process of adsorption on the metal surface. The inhibition efficiency should follow the sequence $\mathrm{O}<\mathrm{N}<\mathrm{S}<\mathrm{P}$. The use of organic compounds containing oxygen, sulphur, and especially nitrogen to reduce corrosion attack on steel has been studied in some detail. The existing data show that most organic inhibitors are adsorbed on the metal surface by displacing water molecules on the surface and forming a compact barrier. The availability of nonbonded (lone pair) and p-electrons in inhibitor molecules facilitate electron transfer from the inhibitor to the metal. A coordination covalent bond involving transfer of electrons from inhibitor to the metal surface may be formed. The strength of the chemisorption bond depends upon the electron density on the donor atom of the functional group and also the polarizability of the group. Replacement of an $\mathrm{H}$ atom attached to a $\mathrm{C}$ atom in the ring by a substituent group $\left(-\mathrm{NH}_{2},-\mathrm{NO}_{2},-\mathrm{CHO}\right.$, or $-\mathrm{COOH})$ improves inhibition [88]. The electron density in the metal at the point of attachment changes resulting in retardation of cathodic or anodic reactions. Electrons are consumed at the cathode and are furnished at the anode. Thus, corrosion is retarded. Straight chain amines containing between three and fourteen carbons have been examined. Inhibition increases with carbon number in the chain to about 10 carbons, but, with higher members, little increase or decrease in the ability to inhibit corrosion occurs. This is attributed to the decreasing solubility in aqueous solution with increasing length of the hydrocarbon chain. However, the presence of a hydrophilic functional group in the molecule would increase the solubility of the inhibitors.

The performance of an organic inhibitor is related to the chemical structure and physicochemical properties of the compound like functional groups, electron density at the donor atom, $p$-orbital character, and the electronic structure of the molecule. 
The inhibition could be due to (i) adsorption of the its molecules or ions on anodic and/or cathodic sites, (ii) increase in cathodic and/or anodic overvoltage, and (iii) the formation of a protective barrier film. Some factors that contribute to the action of inhibitors are (i) chain length, (ii) size of the molecule, (iii) bonding, aromatic/conjugate, (iv) strength of bonding to the substrate, (v) cross-linking ability, and (vi) solubility in the environment.

The role of inhibitors is to form a barrier of one or more molecular layers against acid attack. This protective action is often associated with chemical and/or physical adsorption involving a variation in the charge of the adsorbed substance and charge transfer from one phase to another. Sulphur and/or nitrogen-containing heterocyclic compounds with various substituents are considered to be effective corrosion inhibitors. Thiophene and hydrazine derivatives offer special affinity to inhibit corrosion of metals in acid solutions. Inorganic substances such as phosphates, chromates, dichromates, silicates, borates, tungstates, molybdates, and arsenates have been found effective as inhibitors of metal corrosion. Pyrrole and its derivatives are believed to exhibit good protection against corrosion in acidic media. These inhibitors have also found useful application in the formulation of primers and anticorrosive coatings, but a major disadvantage is their toxicity and as such their use has come under severe criticism. Among the alternative corrosion inhibitors, organic substances containing polar functions with nitrogen, sulphur, and/or oxygen in the conjugated system have been reported to exhibit good inhibiting properties. The inhibitive characteristics of such compounds derive from the adsorption ability of their molecules, with the polar group acting as the reaction center for the adsorption process. The resulting adsorbed film acts as a barrier that separates the metal from the corrodent, and the inhibition efficiency depends on the mechanical, structural, and chemical characteristics of the adsorption layers formed under particular conditions [89].

\subsection{Coherent shock wave inhibitor:}

One of the major advantages of the laser materials processing is the possibility of accurate control of the area where laser radiation should be delivered, as well as the amount and rate of energy deposition since laser beams can be easily directed to fatigue-critical areas without masking. Only the amount of the laser beam energy that is absorbed by the material can contribute to processes like heating and melting. The specific properties of laser beam that enable and justify their use in such a wide spectrum of applications are: spatial and temporal coherence (i.e. phase and amplitude are unique), low divergence (parallel to the optical axis), high continuous or pulsed power density and monochromaticity [90,91]. The laser-solid interaction is a highly complex and interrelated process because of its dependence on laser parameters such as power density, wavelength, pulse duration, and spot size, besides the material's physical properties, e.g., absorption properties, morphology, homogeneity, melting and boiling points. The mechanisms involved in the laser-solid interaction have been studied extensively, but they are still not fully understood. However it can be controlled and highly reproducible to enable analytical measurement capabilities [92, 93]. Figures 1 and 2 represent SEM micrographs of St-37 surface corrosion with and without coherent shock 
wave treatment. Results were obtained that the values of corrosion rate decreased after laser shock. [94-99].

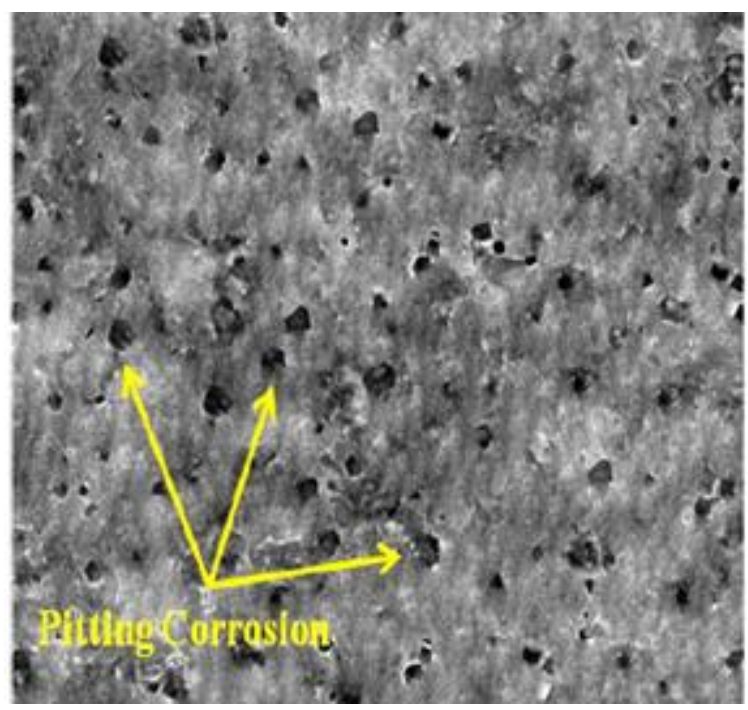

Figure 1. SEM micrograph of St-37 surface corrosion without coherent wave pulses.

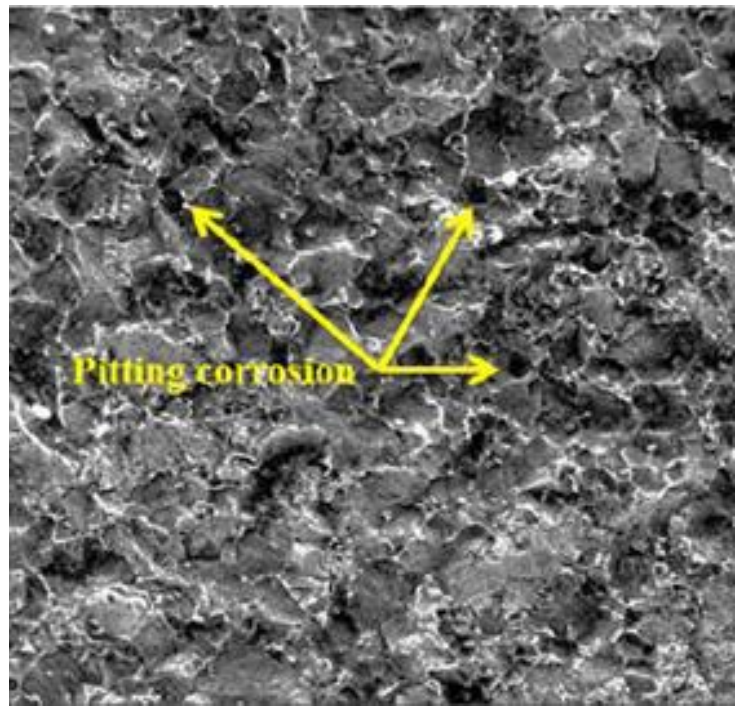

Figure 2. SEM micrograph of St-37 surface corrosion with coherent wave pulses.

\section{Mechanism of action}

In general, the types of adsorption can be distinguished as physical adsorption mechanism or chemical adsorption mechanism or mixed type mechanism depending on interactions between metallic surface and heteroatoms and/or $p$-electrons of the inhibitor molecules [100]. There are parameters which determine the mechanism type. These parameters related to inhibitors include the chemical structure and charge distribution, and the other one is related to the metal surface charge. In the physical adsorption mechanism, the charges on organic inhibitor molecules bind with the electrically charged metal surface, whereas chemical adsorption occurs through a chemical reaction between unshared free pairs of 
electrons and an unoccupied $d$-orbital of the metal surface to produce coordination chemical bonds [101]. The inhibition efficiency of organic inhibitor molecules is improved when one of the hydrogen atoms at a carbon atom in the heterocyclic ring is substituted by aldehyde, nitrosyl, carboxyl, or amino substituent groups [102]. Also, anodic or cathodic reactions are retarded when electron density changes on the metal at the point of attachment [103].

In corrosion investigations, natural or organic inhibitors are added to corrosive environments and metal or alloy samples are exposed to the corrosive environment for some period. The metal mass loss and exposure time are used to calculate the corrosion rate. The presence of an organic inhibitor in the acidic environment will reduce the metal mass loss, thus reducing the corrosion rate. There are various models in research investigations which demonstrate the mechanism of inhibitors' action. In the best model which is well accepted [104], the inhibitor molecules are adsorbed on the corroded surface of a metal; generally adsorption ensures the removal of water molecules absorbed on the metal surface (Equation 1).

$$
\operatorname{Org}_{(\text {sol })}+a \mathrm{H}_{2} \mathrm{O}_{(\text {ads })} \leftrightarrow \operatorname{Org}_{(\text {ads })}+a \mathrm{H}_{2} \mathrm{O}_{\text {(sol) }}
$$

Four basic absorption methods are related to inhibitor molecules on the metal surfaces: physical adsorption (electrostatic adsorption), chemical absorption (formation of coordination bonds between the metal surface in inhibitor molecules - organometallic complexes). Moreover, the stability of the membranes/layer of the organic inhibitor molecules adsorbed on the metallic surface depends on the active sites, aromatic rings, potential steric hindrance, electron densities in inhibitor molecules, the type of acidic solution, and the nature of interaction between a $p$-orbital and iron atoms $d$-orbital. The basic information concerning the absorption mode of organic molecules on a metal surface can be extracted from the adsorption isotherm. Various isotherms such as Langmuir (Equation 2), Flory-Huggins (Equation 3), Temkin (Equation 4) and Freundlich (Equation 5) could explain the anti-corrosion mechanism [105].

$$
\begin{gathered}
\text { Langmuir isotherm: } \frac{C}{\theta}=\frac{1}{K_{\mathrm{ads}}}+C \\
\text { Flory-Huggins isotherm: } \log \left(\frac{C}{\theta}\right)=\log \left(K_{\mathrm{ads}}\right)+a \log C \\
\text { Temkin isotherm: } \theta=\frac{1}{f} \ln K_{\mathrm{ads}} C
\end{gathered}
$$

Freundlich isotherm: $\log \theta=\log \left(K_{\mathrm{ads}}\right)+n \log C$

where $C$ is the concentration of the inhibitor, $\theta$ is the surface coverage degree, $K_{\text {ads }}$ is a constant, $f$ is the energetic parameter, and $a$ is the water molecules on the surface of metal. 
The adsorption of organic molecules on the metal surface is also affected by the structure of inhibitor molecules, charge density on the metal surface and zero charge potency of the metal.

Surface charge calculation provides insights into the nature of the metal/inhibitor interaction. The surface charge is the locus of the $E_{\text {cor }}$ corrosion potential with respect to the zero charge potential $\left(E_{\mathrm{q}}\right)$. When the difference $E_{\mathrm{r}}=E_{\text {cor }}-E_{\mathrm{q}}=0$ is negative, where $E_{\mathrm{r}}$ is the probability of "rational" Antropov corrosion, the electrode surface has a net negative charge and the cation adsorption is preferred, that is, the positive form of the inhibitor is absorbed directly onto the steel by substituting a proton in a water molecule. Conversely, when $E_{\mathrm{r}}$ becomes positive, the anions are adsorbed and, therefore, the anions $\left(\mathrm{Cl}^{-}\right.$or $\left.\mathrm{SO}_{4}^{2-}\right)$ are adsorbed on the metal surface, and then the interaction with a protonated inhibitor molecule is expected. This condition favors the formation of a film that prevents the reaction between the metal and the solution [106]. If $E_{\mathrm{r}}$ is equal to zero, neither the cations nor the anions of the solution interact with the metal; then the inhibitor molecule interacts through its electrons with the unoccupied d-orbital of iron atoms.

Recently, the utilization of quantitative chemical techniques such as modified neglect of diatomic overlap (MNDO), density-functional theory (DFT), Austin model (AM1), parametric method (PM3) and many other studies have gained attention as powerful tools to determine the basic parameters of adsorption and corrosion prevention mechanisms. Quantum parameters such as the boundary orbital energy of HOMO (highest occupied molecular orbital) and LUMO (lowest unoccupied molecular orbital), Mulliken charges, ionization energy, electron affinity, stiffness, electrical endurance index, back bond, and inhibitor electrostatic voltage map are generators for studying corrosion [107]. But nowadays, both ab initio and DFT have become attractive theoretical methods since they provide accurate fundamental parameters even for massive complex particles (multi-electron systems). In the ab initio computation, HF, the average Coulombian repulsion between electron and electron is considered for further determination of quantum parameters. DFT uses electronic density as the base parameter instead of the electronic wave function. Using complex computational tools and some basics, the HSAB concept (the exact nature of interactions between a metal surface and an organic molecule depends on the relative coordination strength towards the metal, and for specific groups present in the molecule) provides a systematic method for analyzing a metal inhibitor/reaction. Thus, it is possible to ascertain a suitable inhibition mechanism. These techniques that support electrochemical studies help us to understand the mechanism of the inhibitor molecule reaction [108].

(A) Forces of electrostatic attraction between the charged particles of the inhibitor and the metal surface,

(B) Interaction of unpaired electron pairs in the molecule with the metal,

(C) The interaction of electrons of double bonds with the metal surface,

(D) A combination of (A) and (C). 
The inhibitor molecules have the ability to block the anodic and/or cathodic site which prevent the metal dissolution or hydrogen evolution reactions. The postulated mechanism is that corrosion occurs through the metal dissolution and hydrogen evolution [109].

The dissolution of metals occurs according to equations (6-9).

$$
\begin{gathered}
\mathrm{Fe}+\mathrm{Cl}^{-} \rightarrow\left(\mathrm{FeCl}^{-}\right)_{\mathrm{ads}} \\
\left(\mathrm{FeCl}^{-}\right)_{\mathrm{ads}} \rightarrow(\mathrm{FeCl})_{\mathrm{ads}}+\mathrm{e}^{-} \\
(\mathrm{FeCl})_{\mathrm{ads}}+\mathrm{e}^{-} \rightarrow \mathrm{FeCl}^{+}+\mathrm{e}^{-} \\
\mathrm{FeCl}^{+}+\mathrm{e}^{-} \rightarrow \mathrm{Fe}^{++}+\mathrm{Cl}^{-}
\end{gathered}
$$

Cathodic evolution hydrogen can occur according to equations (10-12).

$$
\begin{gathered}
\mathrm{Fe}+\mathrm{H}^{+} \rightarrow\left(\mathrm{FeH}^{+}\right)_{\mathrm{ads}} \\
(\mathrm{FeH})_{\mathrm{ads}}+\mathrm{e}^{-} \rightarrow(\mathrm{FeH})_{\mathrm{ads}} \\
(\mathrm{FeH})_{\mathrm{ads}}+\mathrm{H}^{+}+\mathrm{e}^{-} \rightarrow \mathrm{Fe}+\mathrm{H}_{2}
\end{gathered}
$$

Anodes and cathodes are the two corrosion cells generally used to demonstrate the transfer of charges between iron and electrolyte as well as within iron itself. The presence of charged ions in the electrolyte causes the solution to become electrically conductive. During the corrosion process, the metal ions move from the active site (anode) into the solution and pass the electrons from the metal at the lower active site (cathode) to an acceptor. Electron acceptors like oxygen, oxidizing agents, or hydrogen ions are required for the cathodic process to take place. Equation (13) represents the general chemical corrosion reaction in the presence of oxygen in moist air. Figure 3 signifies the basic electrochemical cell built using the anode and cathode cells partially immersed into an electrolyte. The anode cell experiences rusting during the oxidation process, whereas the cathode cell reduces but does not rust. In the production of oil and gas, $\mathrm{Fe}^{2+}$ ions are produced at the anode when iron from steel is driven into the solution. These ions react with oxygen, hydrogen sulfide, or carbon dioxide to form decay yields as presented below. The additional electrons change from the anode to the cathode where hydroxyl ions are produced by reducing water. The hydrogen ions are converted to hydrogen gas by the electrons if oxygen does not exist at the cathode. The anodic and cathodic positions are regions on the outer surface of the metal that vary in electric potential. Due to the occurrence of salts, the electrolyte is normally formed from water to become conductive [110].

The chemical reaction of corrosion is given as follows:

$$
4 \mathrm{Fe}+3 \mathrm{O}_{2}=2 \mathrm{Fe}_{2} \mathrm{O}_{3}
$$




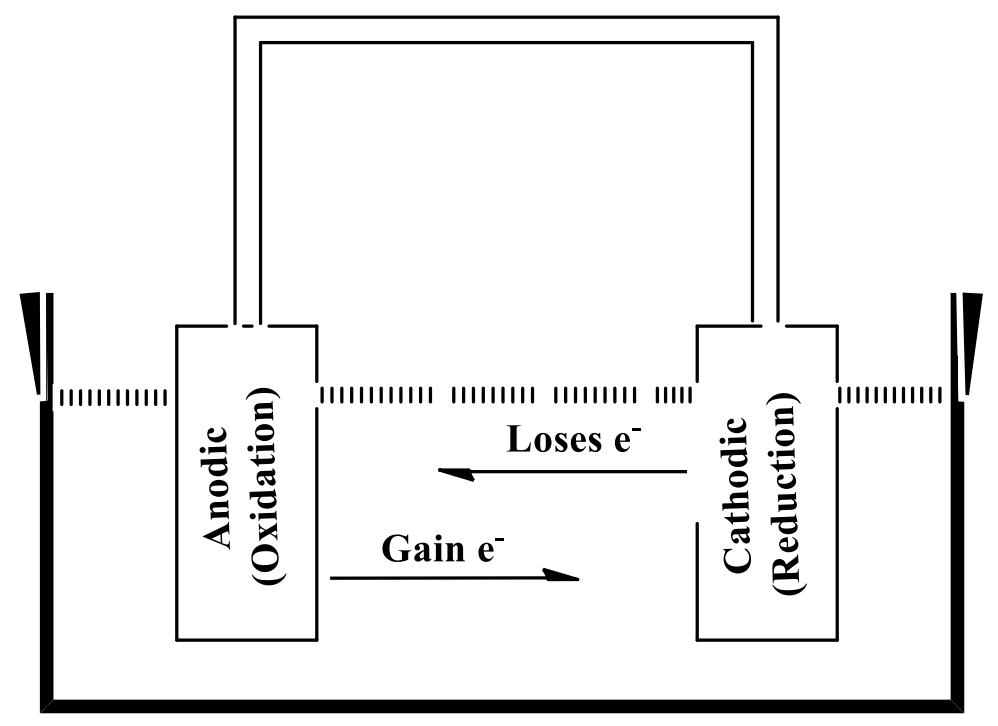

Figure 3. Electrochemical cell [111].

The mechanism of action of organic corrosion inhibitors is based on the adsorption on the surface to form protective films which displace water from the metal surface and protect it against deteriorating. This process is not either purely physical or purely chemical adsorption. Adsorption is influenced by the chemical structure of organic inhibitors, nature and surface charge, the distribution of charge in the molecule and type of aggressive media ( $\mathrm{pH}$ and/or electrode potential). Physical adsorption is based on electrostatic interaction between the charged metal surface and charged inhibitor molecule. Chemical adsorption is connected with the donor-acceptor interactions between free electron pairs and vacant, low energy d-orbital of metal (Figure 4).

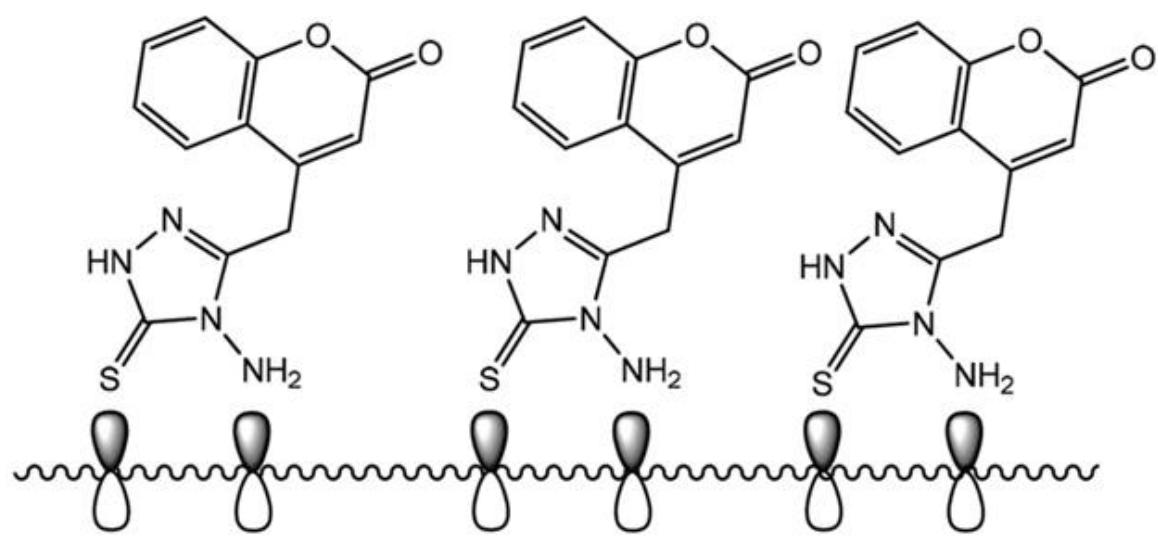

Figure 4. Schematic diagram representing the adsorption mechanism of inhibitor molecules on mild steel surface [109].

Effective organic corrosion inhibitors should contain heteroatoms (nitrogen, oxygen, sulfur and phosphorus) with lone electron pairs and a moiety with $\pi$-electrons (aromatic rings and multiple bonds) that can interact with free $\mathrm{d}$ orbital of the metal, favoring the adsorption process [112]. 
The standard adsorption free energy $\left(\Delta G_{\mathrm{ads}}^{0}\right)$ gives information about the type of adsorption. Values up to $-20 \mathrm{~kJ} / \mathrm{mol}$ are connected with the electrostatic interaction (physical adsorption). More negative values, below $-40 \mathrm{~kJ} / \mathrm{mol}$, correspond to a chemisorption process. Negative values mean that both processes are spontaneous. Also the standard enthalpy of adsorption provides valuable information about the mechanism of corrosion inhibition. An endothermic adsorption process $\left(\Delta H_{\text {ads }}^{0}>0\right)$ is attributed to chemisorption, whereas an exothermic adsorption $\left(\Delta H_{\text {ads }}^{0}<0\right)$ is connected to physical or physical/chemical adsorption processes. The presence of heteroatoms with lone pair of electrons like nitrogen, oxygen, sulfur or phosphorus as well as $\pi$-electrons of multiple bonds or aromatic rings enhance adsorption phenomena [113]. Chemisorption involves transfer or sharing of unbonded electrons between the inhibitor molecule and the metal surface [114].

The inhibitor is chemically adsorbed on the metal surface and forms a protective thin film or chemical bonds form by reaction a between the inhibitor and the metal. The adsorption mechanism of organic inhibitors can occur via one of these routes:

$1^{\text {st }}$, charged molecules and a metal are attracted electrostatically.

$2^{\text {nd }}$, interaction between unpaired electrons and the metal surface.

$3^{\text {rd }}$, interaction between $\pi$-electrons and the metal surface.

Organic inhibitors protect the metal surface by blocking cathodic or anodic reactions or both and forming insoluble complexes. The inhibition efficiency of a corrosion inhibitor against corrosion of mild steel in a corrosive environment can be explained according to the number of adsorption sites, charge density, molecular size, mode of interaction with the metal surface and ability to form an insoluble metal complex. Figure 5 is an example of the bonding between inhibitor molecules and mild steel surface. The $\pi$ electrons of the double bonds and the free electrons on the oxygen and nitrogen atoms form chemical bonds with the metal surface as shown in Figure 5.

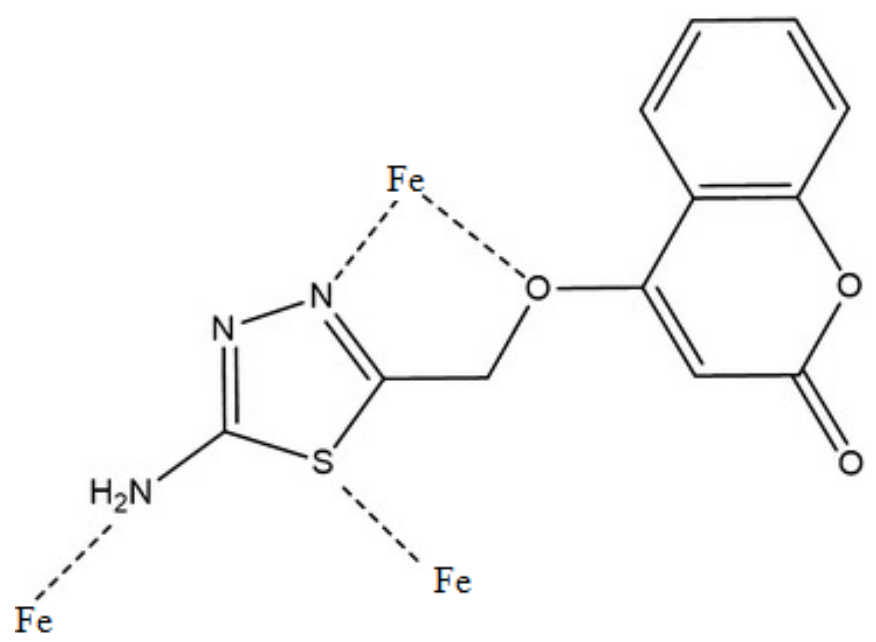

Figure 5. The mechanism of action of an organic inhibitor molecule as a corrosion inhibitor. 


\section{Conclusion}

Current work includes a study of organic corrosion inhibitors. It defines metal corrosion as the spontaneous destruction of metals through chemical and electrochemical interactions with the surrounding environment. Thus, this is exactly the opposite of extracting metals from ores. In most environments, metals are not inherently stable, but they do tend to revert to more stable compounds, a process called corrosion. Corrosion is also defined as a deterioration in the intrinsic properties of a substance as a result of its interaction with one of the components of the environment, as most of the corrosion phenomena that occur are mainly electrochemical in nature and involve the presence of metal contact with the electrolyte and transfer of free valence electrons. A popular example of metal corrosion is iron rust. Corrosion is one of the problems that pose a serious threat to many industries due to the damage it causes to metal parts, especially those made of steel. Therefore, the present work represents a study on organic inhibitors and their importance, as well as a review of some organic corrosion inhibitors.

\section{Funding}

This research received no external funding.

\section{Acknowledgments}

The authors are grateful to the University Kebangsaan Malaysia (UKM) for support.

\section{Conflicts of Interest}

The authors declare no conflict of interest.

\section{References}

1. N. Thompson, M. Yunovich and D. Dunmire, Cost of corrosion and corrosion maintenance strategies, Corros. Rev., 2007, 25, 247-262. doi: 10.1515/CORRREV.2007.25.3-4.247

2. D. Mahmood, A.K. Al-Okbi, M.M. Hanon, K.S. Rida, A.F. Alkaim, A.A. Al-Amiery, A. Kadhum and A.A.H. Kadhum, Carbethoxythiazole corrosion inhibitor: as an experimentally model and DFT theory, J. Eng. Appl. Sci. (Faisalabad, Pak.), 2018, 13, 3952-3959. doi: 10.3923/jeasci.2018.3952.3959

3. A. Kadhim, E.T. Salim, S.M. Fayadh, A.A. Al-Amiery, A.A.H. Kadhum and A. Mohamad, Effect of Multipath Laser Shock Processing on Microhardness, Surface Roughness And Wear Resistance of 2024-T3 Al Alloy, Sci. World J., 2014, 1-6. doi: $\underline{10.1155 / 2014 / 490951}$

4. A. Alobaidy, A. Kadhum, S. Al-Baghdadi, A. Al-Amiery, A. Kadhum, E. Yousif and A.B. Mohamad, Eco-friendly corrosion inhibitor: experimental studies on the corrosion inhibition performance of creatinine for mild steel in $\mathrm{HCl}$ complemented with quantum chemical calculations, Int. J. Electrochem. Sci., 2015, 10, 3961-3972. 
5. S. Junaedi, A.A.H. Kadhum, A.A. Al-Amiery, A.B. Mohamad and M.S. Takriff, Synthesis and characterization of novel corrosion inhibitor derived from oleic acid: 2Amino 5-Oleyl-1,3,4-Thiadiazol (AOT), Int. J. Electrochem. Sci., 2012, 7, no. 4, $3543-$ 3554.

6. A.Y.I. Rubaye, K.S. Rida, A.Q. Salam and A. Al-Amiery, Acetamidocoumarin as a based eco-friendly corrosion inhibitor, Int. J. ChemTech Res., 2016, 9, 39-47.

7. H.J. Habeeb, H.M. Luaibi, T.A. Abdullah, R.M. Dakhil, A.A.H. Kadhum and A.A. AlAmiery, Case study on thermal impact of novel corrosion inhibitor on mild steel, Case Stud. Therm. Eng., 2018, 12, 64-68. doi: 10.1016/j.csite.2018.03.005

8. S.S. Al-Taweel, K.W.S. Al-Janabi, H.M. Luaibi, A.A. Al-Amiery and T.S. Gaaz, Evaluation and characterization of the symbiotic effect of benzylidene derivative with titanium dioxide nanoparticles on the inhibition of the chemical corrosion of mild steel, Int. J. Corros. Scale Inhib., 2019, 8, no. 4, 1149-1169. doi: 10.17675/2305-6894-2019$\underline{8-4-21}$

9. F. Mansfeld, Use of electrochemical impedance spectroscopy for the study of corrosion protection by polymer coatings, J. Appl. Electrochem., 1995, 25, 187-202. doi: $10.1007 / \mathrm{bf} 00262955$

10. A. Kahyarian, A. Schumaker, B. Brown and S. Nesic, Acidic corrosion of mild steel in the presence of acetic acid: Mechanism and prediction, Electrochim. Acta, 2017, 258, 639-652. doi: $10.1016 /$ j.electacta.2017.11.109

11. H.R. Obayes, A.A. Al-Amiery, G.H. Alwan, T.A. Abdullah, A.A.H. Kadhum and A.B. Mohamad, Sulphonamides as corrosion inhibitor: Experimental and DFT studies, J. Mol. Struct., 2017, 1138, 1-9. doi: $\underline{10.1016 / j . m o l s t r u c .2017 .02 .100}$

12. D.M. Jamil, A.K. Al-Okbi, S.B. Al-Baghdadi, A.A. Al-Amiery, A. Kadhim, T.S. Gaaz, A.A.H. Kadhum and A.B. Mohamad, Experimental and theoretical studies of Schiff bases as corrosion inhibitors, Chem. Cent. J., 2018, 12, no. 1, 1-9. doi: 10.1186/s13065018-0376-7

13. M.H.O. Ahmed, A.A. Al-Amiery, Y.K. Al-Majedy, A.A.H. Kadhum, A.B. Mohamad, and T.S. Gaaz, Synthesis and characterization of a novel organic corrosion inhibitor for mild steel in $1 \mathrm{M}$ hydrochloric acid, Results Phys., 2018, 8, 728-733. doi: 10.1016/j.rinp.2017.12.039

14. T.A. Salman, D.S. Zinad, S.H. Jaber, M. Al-Ghezi, A. Mahal, M.S. Takriff and A.A. AlAmiery, Effect of 1,3,4-Thiadiazole Scaffold on the Corrosion Inhibition of Mild Steel in Acidic Medium: An Experimental and Computational Study, J. Bio- Tribo-Corros., 2019, 5, no. 2, 1-11. doi: 10.1007/s40735-019-0243-7

15. O.K. Abiola, N.C. Oforka, E.E. Ebenso, and N.M. Nwinuka, Eco- friendly corrosion inhibitors the inhibitive action of Delonuix regia extract for the corrosion of aluminum in acidic media, Anti-Corros. Methods Mater., 2007, 54, 219-224. doi: $\underline{10.1108 / 00035590710762357}$ 
16. H.J. Habeeb, H.M. Luaibi, R.M. Dakhil, A.A.H. Kadhum, A.A. Al-Amiery and T.S. Gaaz, Development of new corrosion inhibitor tested on mild steel supported by electrochemical study, Results Phys., 2018, 8, 1260-1267. doi: 10.1016/j.rinp.2018.02.015

17. D.A. Williams, P.K. Holifield, J.R. Looney and L.A. McDougall, Method of Inhibiting Corrosion in Acidizing Wells, in: US Patent 5,200,096, Exxon Chemicals Patents, Inc., Linden, N.J., 1993.

18. D.A. Williams, P.K. Holifield, J.R. Looney and L.A. McDougall, Inhibited Acid System for Acidizing Wells, in: US Patent 5,209,859, Exxon Chemical Patents, Inc., Linden, N.J., 1993.

19. D.A. Williams, P.K. Holifield, J.R. Looney and L.A. McDougall, Corrosion Inhibitor and Method of Use, in: US Patent 5,002,673, Exxon Chemical Patents Inc., Linden, N.J., 1991.

20. E. Barmatov, J. Geddes, T. Hughes and M. Nagl, Research on corrosion inhibitors for acid stimulation, NACE Int., 2012, 2012-0001573.

21. M.A. Quraishi and D. Jamal, Corrosion inhibition of N-80 steel and mild steel in $15 \%$ boiling hydrochloric acid by a triazole compound - SAHMT, Mater. Chem. Phys., 2001, 68, 283-287. doi: 10.1016/S0254-0584(00)00369-2

22. G. Schmitt, Application of inhibitors for acid media, Br. Corros. J., 1984, 19, 165-176. doi: $10.1179 / 000705984798273100$

23. S. Sığırcık, T. Tüken and M. Erbil, Assessment of the inhibition efficiency of 3,4diaminobenzonitrile against the corrosion of steel, Corros. Sci., 2016, 102, 437-445. doi: $10.1016 /$ j.corsci.2015.10.036

24. K. Srivastav and P. Srivastava, Studies on plant materials as corrosion inhibitors, $B r$. Corros. J., 1981, 16, no. 4, 221-223. doi: $\underline{10.1179 / 000705981798274788}$

25. F. Zucchi and I. Omar, Plant extracts as corrosion inhibitors of mild steel in $\mathrm{HCl}$ solutions, Surf. Technol., 1985, 24, 391-399. doi: 10.1016/0376-4583(85)90057-3

26. S. Zakvi and G. Mehta, Acid corrosion of mild steel and its inhibition by Swertia angustifolia - study by electrochemical techniques, Trans. SAEST, 1988, 23, 407-410.

27. U. Ekpe, E. Ebenso and U. Ibok, Inhibitory action of Azadirachta indica leaves extract on the corrosion of mild steel in $\mathrm{H}_{2} \mathrm{SO}_{4}$, West Afr. J. Biol. Appl. Chem., 1994, 37, $13-$ 30 .

28. M. Quraishi, I. Farooqi and P. Saini, Investigation of some green compounds as corrosion and scale inhibitors for cooling systems, Corrosion, 1999, 55, 493-497. doi: $10.5006 / 1.3284011$

29. P. Sakthivel, P. Nirmala, S. Umamaheswari, A. Antony, G. Kalaignan, A. Gopalan and T. Vasudevan, Corrosion inhibition of mild steel by extracts of Pongamia glabra and Annona squamosa in acidic media, Bull. Electrochem., 1999, 15, 83-86.

30. S. Verma and G. Mehta, Effect of acid extracts of Acacia arabica on acid corrosion of mild steel, Bull. Electrochem., 1999, 15, 67-70. 
31. A. El-Etre and M. Abdallah, Natural honey as corrosion inhibitor for metals and alloys. II. C-steel in high saline water, Corros. Sci., 2000, 42, 731-738. doi: 10.1016/S0010938X(99)00106-7

32. S. Martinez and I. Stern, Inhibitory mechanism of low-carbon steel corrosion by mimosa tannin in sulphuric acid solutions, J. Appl. Electrochem., 2001, 31, 973-978. doi: 10.1023/A:1017989510605

33. A. El-Etre, Inhibition of acid corrosion of aluminum using vaniline, Corros. Sci., 2001, 43, 1031-1039. doi: 10.1016/S0010-938X(00)00127-X

34. M. Quraishi and D. Jamal, Approach to corrosion inhibition by some green inhibitors based on oleochemicals, Bull. Electrochem., 2002, 18, 289-294.

35. E. Khamis and N. Alandis, Herbs as new type of green inhibitors for acidic corrosion of steel, Materialwiss. Werkstofftech., 2002, 33, 550-554. doi: 10.1002/15214052(200209)33:9<550::AID-MAWE550>3.0.CO;2-G

36. K. Parikh and K. Joshi, Natural compounds onion (Allium cepa), garlic (Allium sativum) and bitter gourd (Momordica charantia) as corrosion inhibitors for mild steel in hydrochloric acid, Trans. SAEST, 2004, 39, 29-35.

37. M. Abdallah, Guar gum as corrosion inhibitor for carbon steel in sulfuric acid solutions, Port. Electrochim. Acta. 2004, 22, 161-175. doi: 10.4152/pea.200402161

38. G. Gunasekaran and L. Chauhan, Eco friendly inhibitor for corrosion inhibition of mild steel in phosphoric acid medium, Electrochim. Acta, 2004, 49, 4387-4395. doi: 10.1016/j.electacta.2004.04.030

39. K. Orubite and N. Oforka, Inhibition of the corrosion of mild steel in hydrochloric acid solutions by the extracts of leaves of Nypa fruticans Wurmb., Mater. Lett., 2004, 58, 1768-1772. doi: 10.1016/j.matlet.2003.11.030

40. N. Anthon, E. Malarvizhi, P. Maheshwari, S. Rajendran and N. Palaniswamy, Corrosion inhibition of caffein $-\mathrm{Mn}^{2+}$ system, Indian J. Chem. Technol., 2004, 11, 346-350.

41. E. Chaieb, A. Bouyanzer, B. Hammouti and M. Benkaddour, Inhibition of the corrosion of steel in $1 \mathrm{M} \mathrm{HCl}$ by eugenol derivatives, Appl. Surf. Sci., 2005, 246, 199-206. doi: 10.1016/j.apsusc.2004.11.011

42. R. Sathiyanathan, S. Maruthamuthu, M. Selvanayagam, S. Mohanan and N. Palaniswamy, Corrosion inhibition of mild steel by ethanolic extracts of Ricinus communis leaves, Indian J. Chem. Technol., 2005, 12, 356-360.

43. Y. Li, P. Zhao, Q. Liang and B. Hou, Berberine as a natural source inhibitor for mild steel in $1 \mathrm{M} \mathrm{H} \mathrm{H}_{2} \mathrm{SO}_{4}$, Appl. Surf. Sci., 2005, 252, 1245-1253. doi: 10.1016/j.apsusc.2005.02.094

44. A. Abdel-Gaber, B. Abd-El-Nabey, I. Sidahmed, A. El-Zayady and M, Saadawy, Inhibitive action of some plant extracts on the corrosion of steel in acidic media, Corros. Sci., 2006, 48, 2765-2779. doi: 10.1016/j.corsci.2005.09.017

45. S. Umoren and U. Ekanem, Inhibition of mild steel corrosion in $\mathrm{H}_{2} \mathrm{SO}_{4}$ using exudate gum from Pachylobus edulis and synergistic potassium halide additives, Chem. Eng. Commun., 2010, 197, 1339-1356. doi: $\underline{10.1080 / 00986441003626086}$ 
46. S. Garai, P. Jaisankar, J. Singh and A. Elango, Comprehensive study on crude methanolic extract of Artemisia pallens (Asteraceae) and its active component as effective corrosion inhibitors of mild steel in acid solution, Corros. Sci., 2012, 60, 193 204. doi: $10.1016 /$ j.corsci.2012.03.036

47. S. Aribo, S. Olusegun, L. Ibhadiyi, A. Oyetunji and D. Folorunso, Green inhibitors for corrosion protection in acidizing oilfield environment, J. Assoc. Arab Univ. Basic Appl. Sci., 2017, 24, 34-38. doi: 10.1016/j.jaubas.2016.08.001

48. M. Gobara, B. Zaghloul, A. Baraka, M. Elsayed, M. Zorainy, M.M. Kotb and H. Elnabarawy, Green corrosion inhibition of mild steel to aqueous sulfuric acid by the extract of Corchorus olitorius stems, Mater. Res. Express, 2017, 4, 046504. doi: 10.1088/2053-1591/aa664a

49. N. Negm, N. Kandile, I. Aiad and M. Mohammad, New eco-friendly cationic surfactants synthesis, characterization and applicability as corrosion inhibitors for carbon steel in $1 \mathrm{M} \mathrm{HCl}$, Colloids Surf., A, 2011, 391, 224-233. doi: 10.1016/j.colsurfa.2011.09.032

50. F. Chemat, M. Vian and G. Cravotto, Green extraction of natural products: Concept and principles, Int. J. Mol. Sci., 2012, 13, 8615-8627. doi: 10.3390/ijms13078615

51. A. El-Etre, Inhibition of C-steel corrosion in acidic solution using the aqueous extract of zallouh root, Mater. Chem. Phys., 2008, 108, 278-282. doi: 10.1016/j.matchemphys.2007.09.037

52. G. Ji, P. Dwivedi, S. Sundaram and R. Prakash, Inhibitive effect of Chlorophytum borivilianum root extract on mild steel corrosion in $\mathrm{HCl}$ and $\mathrm{H}_{2} \mathrm{SO}_{4}$ solutions, Ind. Eng. Chem. Res., 2013, 52, 10673-10681. doi: 10.1021/ie4008387

53. G. Ji, P. Dwivedi, S. Sundaram and R. Prakash, Aqueous extract of Argemone Mexicana roots for effective protection of mild steel in an $\mathrm{HCl}$ environment, Res. Chem. Intermed., 2016, 42, 439-459. doi: 10.1007/s11164-015-2029-y

54. Z. Aida, A. Razika, M. Laid, B. Kamel and S. Boualem, Inhibition of acid corrosion of mild steel by aqueous nettle extracts, Pigm. Resin Technol., 2014, 43, 127-138. doi: 10.1108/PRT-11-2012-0078

55. K. Devarayan, G. Mayakrishnan and N. Sulochana, Green inhibitors for corrosion of metals: A review, Chem. Sci. Rev. Lett., 2012, 1, 1-8.

56. A.K. Khudhair, A.M. Mustafa, M.M. Hanoon, A. Al-Amiery, L. M.Shaker, T. Gazz, A.B. Mohamad, A.H. Kadhum and M.S. Takriff, Experimental and Theoretical Investigation on the Corrosion Inhibitor Potential of N-MEH for Mild Steel in HCl, Prog. Color Colorants Coat., 2022, 15, 111-122.

57. E. McCafferty, Thermodynamic aspects of the crevice corrosion of iron in chromate/chloride solutions, J. Electrochem. Soc., 1979, 126, 391-401. doi: 10.1016/0010-938X(89)90094-2

58. M. Bethencourt, F. Botana, J. Calvino, M. Marcos and M. Rodriguez-Chacon, Lanthanide compounds as environmentally-friendly corrosion inhibitors of aluminium alloys: A review, Corros. Sci., 1998, 40, 1803-1819. doi: 10.1016/S0010$\underline{938 X(98) 00077-8}$ 
59. L. Michodjehoun-Mestres，S. Jean-Marc，H. Fulcrand，C. Bouchut， M. Reynes and B. Jean-Marc, Characterisation of highly polymerised prodelphinidins from skin and flesh of four cashew apple (Anacardium occidentale L.) genotypes, Food Chem., 2009, 114, 989-995. doi: $10.1016 /$ j.foodchem.2008.10.052

60. D.S. Zinad, Q.A. Jawad, M.A.M. Hussain, A. Mahal, L. Mohamed, and A.A. AlAmiery, Adsorption, temperature and corrosion inhibition studies of a coumarin derivatives corrosion inhibitor for mild steel in acidic medium: Gravimetric and theoretical investigations, Int. J. Corros. Scale Inhib., 2020, 9, no. 1, 134-151. doi: 10.17675/2305-6894-2020-9-1-8

61. F.G. Hashime, T.A. Salman, S.B. Al-Baghdadis, T. Gaaz and A.A. Al-Amiery, Inhibition Effect of Hydrazine-Derived Coumarin on a Mild Steel Surface in Hydrochloric acid, TRIBOLOGIA Finnish J. Tribol., 2020, 37, 3-4. doi: $10.30678 / \mathrm{fjt} .95510$

62. J.M. Al-Zzyadi, A.A. Kadhim and K. Yao, Electronic and magnetic properties of the (001) surface of the CoNbMnSi Heusler alloy: First-principles calculations, J. Electron Spectrosc. Relat. Phenom., 2018, 226, 17-21. doi: 10.1016/j.elspec.2018.04.005

63. D.A. Mohammed, M.A. Fakhri and A. Kadhim, Reduction the Corrosion Rate of 304 Stainless Steel using Pulsed Laser Shock Penning Method, IOP Conf. Ser.: Mater. Sci. Eng., 2018, 454, 012162. doi: 10.1088/1757-899X/454/1/012162

64. J.M. Al-Zyadi, A.A. Kadhim and K.-L. Yao, Half-metallicity of the (001), (111) and (110) surfaces of CoRuMnSi and interface half-metallicity of CoRuMnSi/CdS, RSC Adv., 2018, 8, 25653-25663. doi: 10.1039/C8RA02918K

65. R.H. Abass, A.M. Haleem, M.K. Hamid, A. Kadhim and R.S. Jawad, Antimicrobial Activity of $\mathrm{TiO}_{2}$ NPs against Escherichia coli ATCC 25922 and Staphylococcus aureus ATCC 25923, Int. J. Comp. Appl. Sci. IJOCAAS, 2017, 2, 6-10.

66. A. Kadhim, R.S. Jawad, N.H. Numan and R.J. Al-Azawi, Determination the wear rate by using XRF technique for Kovar alloy under lubricated condition, Int. J. Comp. Appl. Sci. IJOCAAS, 2, 1-5

67. T.K. Abed, R.S. Jawad, A. Kadhim and S.M. Fayadh, Improvement of the fatigue resistance and increase its life of specimen of naval brass alloy using laser shock wave processing, J. Nanosci. Technol., 2016, 2, 69-72.

68. A.M. Resen, M. Hanoon, R.D. Salim, A.A. Al-Amiery, L.M. Shaker and A.A.H. Kadhum, Gravimetrical, theoretical, and surface morphological investigations of corrosion inhibition effect of 4-(benzoimidazole-2-yl) pyridine on mild steel in hydrochloric acid, Koroze Ochr. Mater., 2020, 64, no. 4, 122-130. doi: 10.2478/kom2020-0018

69. D.S. Zinad, M. Hanoon, R.D. Salim, S.I. Ibrahim, A.A. Al-Amiery, M.S. Takriff and A.A.H. Kadhum, A new synthesized coumarin-derived Schiff base as a corrosion inhibitor of mild steel surface in hcl medium: Gravimetric and DFT studies, Int. J. Corros. Scale Inhib., 2020, 9, no. 1, 228-243. doi: 10.17675/2305-6894-2020-9-1-14 
70. S.B. Al-Baghdadi, A.A. Al-Amiery, T.S. Gaaz and A.H. Kadhum, Terephthalohydrazide and isophthalohydrazide as new corrosion inhibitors for mild steel in hydrochloric acid: Experimental and theoretical approaches, Koroze Ochr. Mater., 2021, 65, no. 1, 12-22. doi: $10.2478 / \mathrm{kom}-2021-0002$

71. W.M. Shakier, A. Kadhim and A.Z. Mohammed, Corrosion inhibitor for St-37 Alloy by Laser Shoch Peenine, J. Adv. Electrochem., 2016, 2, 56-59.

72. A.A. Al-Amiery, A.H. Kadhum, A. Kadihum, A.B. Mohamad, C.K. How and S. Junaedi, Inhibition of Mild Steel Corrosion in Sulfuric Acid Solution by New Schiff Base, Materials, 2014, 7, 787-804. doi: 10.3390/ma7020787

73. D.A. Mohammed, A. Kadhim and M.A. Fakhri, The enhancement of the corrosion protection of 304 stainless steel using $\mathrm{Al}_{2} \mathrm{O}_{3}$ films by PLD method, AIP Conf. Proc., 2018, 2045, 020014. doi: 10.1063/1.5080827

74. A.A. Al-Amiery, A.A.H. Kadhum, A.B. Mohamad and S. Junaedi, A novel hydrazinecarbothioamide as a potential corrosion inhibitor for mild steel in $\mathrm{HCl}$, Materials, 2013, 6, no. 4, 1420-1431. doi: $\underline{10.3390 / \mathrm{ma6041420}}$

75. A.A. Al-Amiery, A.A.H. Kadhum, A. Kadihum, A.B. Mohamad, C.K. How and S. Junaedi, Inhibition of mild steel corrosion in sulfuric acid solution by new Schiff base, Materials, 2014, 7, no. 2, 787-804. doi: 10.3390/ma7020787

76. A.B. Mohamad, A.A.H. Kadhum, A.A. Al-Amiery, L.C. Ying and A.Y. Musa, Synergistic of a coumarin derivative with potassium iodide on the corrosion inhibition of aluminum alloy in $1.0 \mathrm{M} \mathrm{H}_{2} \mathrm{SO}_{4}$, Met. Mater. Int., 2014, 20, 459-467. doi: 10.1007/s12540-014-3008-3

77. A.A. Al-Amiery, A.A.H. Kadhum, A.B. Mohamad, A.Y.Musa and C.J. Li, Electrochemical study on newly synthesized chlorocurcumin as an inhibitor for mild steel corrosion in hydrochloric acid, Materials, 2013, 6, no. 12, 5466-5477. doi: 10.3390/ma6125466

78. E. Yousif, Y.F. Win, A.H. Al-Hamadani, A. Al-Amiery, A.A.H. Kadhum and A.B. Mohamad, Furosemide as an environmental-friendly inhibitor of corrosion of zinc metal in acid medium: Experimental and theoretical studies, Int. J. Electrochem. Sci., 2015, 10, 1708-1718.

79. S.B. Al-Baghdadi, F.T.M. Noori, W.K. Ahmed and A.A. Al-Amiery, Thiadiazole as a potential corrosion inhibitor for mild steel in $1 \mathrm{M} \mathrm{HCl}, J$. Adv. Electrochem., 2016, 2, 67-69.

80. M.H.O. Ahmed, A.A. Al-Amiery, Y.K. Al-Majedy, A.A.H. Kadhum, A.B. Mohamad and T.S. Gaaz, Synthesis and characterization of a novel organic corrosion inhibitor for mild steel in 1 M hydrochloric acid, Results Phys., 2018, 8, 728-733. doi: 10.1016/j.rinp.2017.12.039

81. S. Ahmed, W. Ali and A. Khadom, Synthesis and investigations of heterocyclic compounds as corrosion inhibitors for mild steel in hydrochloric acid, Int. J. Ind. Chem., 2019, 10, 159-173. 10.1007/s40090-019-0181-8 
82. A.A. Al-Amiery, F.A.B. Kassim, A.A.H. Kadhum and A.B. Mohamad, Synthesis and characterization of a novel eco-friendly corrosion inhibition for mild steel in $1 \mathrm{M}$ hydrochloric acid, Sci. Rep., 2016, 6, 19890. doi: 10.1038/srep19890

83. A.A.H. Kadhum, A.B. Mohamad, L.A. Hammed, A.A. Al-Amiery, N.H. San and A.Y. Musa, Inhibition of mild steel corrosion in hydrochloric acid solution by new coumarin, Materials, 2014, 7, no. 6, 4335-4348. doi: 10.3390/ma7064335

84. K. Al-Azawi, S. Al-Baghdadi, A. Mohamed, A.A. Al-Amiery, T.K. Abed, S.A. Mohammed, A.H. Kadhum and A. Mohamad, Synthesis, inhibition effects and quantum chemical studies of a novel coumarin derivative on the corrosion of mild steel in a hydrochloric acid solution, Chem. Cent. J., 2016, 10, 23. doi: 10.1186/s13065-016$\underline{0170-3}$

85. A.A. Al-Amiery, Y.K. Al-Majedy, A.A.H. Kadhum and A.B. Mohamad, New coumarin derivative as an eco-friendly inhibitor of corrosion of mild steel in acid medium, Molecules, 2015, 20, no. 1, 366-383. doi: 10.3390/molecules20010366

86. A.A. Al-Amiery, Coumarin-3-Amine as New Corrosion Inhibitor, Preprints, 2017, 2017070096. doi: 10.20944/preprints201707.0096.v1

87. S.B. Al-Baghdadi, F.G. Hashim, A.Q. Salam, T.K. Abed, T.S. Gaaz, A.A. Al-Amiery, A.A.H. Kadhum, K.S. Reda and W.K. Ahmed, Synthesis and corrosion inhibition application of NATN on mild steel surface in acidic media complemented with DFT studies, Results Phys., 2018, 8, 1178-1184. doi: 10.1016/j.rinp.2018.02.007

88. U.R. Evans, The Corrosion and Oxidation of Metals, Hodder Arnold, 1976.

89. B.E.A. Rani and B.B.J. Basu, Green Inhibitors for Corrosion Protection of Metals and Alloys: An Overview, Int. J. Corros., 2012, 380217, 1-15. doi: 10.1155/2012/380217

90. G. Zhang and C.B. Musgrave, Comparison of DFT methods for molecular orbital eigenvalue calculations, J. Phys. Chem. A, 2007, 111, no. 8, 1554-1561. doi: 10.1021/jp061633o

91. G. Bereket, E. Hur, and C. Ogretir, Quantum chemical studies on some imidazole derivatives as corrosion inhibitors for iron in acidic medium, J. Mol. Struct.: THEOCHEM, 2002, 578, 79-88. doi: 10.1016/S0166-1280(01)00684-4

92. J. Vosta and J. Eliasek, Study on corrosion inhibition from aspect of quantum chemistry, Corros. Sci., 1971, 11, 223-229. doi: 10.1016/S0010-938X(71)80137-3

93. A. Alamiery, L.M. Shaker, T. Allami, A.H. Kadhum and M.S. Takriff, A study of acidic corrosion behavior of Furan-Derived schiff base for mild steel in hydrochloric acid environment: Experimental, and surface investigation, Mater. Today: Proc., 2021, 44, 2337-2341. doi: 10.1016/j.matpr.2020.12.431

94. S. Xia, M. Qiu, L. Yu, F. Liu and H. Zhao, Molecular dynamics and density functional theory study on relationship between structure of imidazoline derivatives and inhibition performance, Corros. Sci., 2008, 50, no. 7, 2021-2029. doi: $\underline{10.1016 / j . c o r s c i .2008 .04 .021 ~}$ 
95. F. Kandemirli and S. Sagdinc, Theoretical study of corrosion inhibition of amides and thiosemicarbazones, Corros. Sci., 2007, 49, no. 5, 2118-2130. doi: 10.1016/j.corsci.2006.10.026

96. C.D. Taylor, R.G. Kelly and M. Neurock, A first-principles analysis of the chemisorption of hydroxide on copper under electrochemical conditions: a probe of the electronic interactions that control chemisorption at the electrochemical interface, $J$. Electroanal. Chem., 2007, 607, 1-2, 167-174. doi: 10.1016/j.jelechem.2007.04.004

97. D. Wang, S. Li, Y. Ying, M. Wang, H. Xiao and Z. Chen, Theoretical and experimental studies of structure and inhibition efficiency of imidazoline derivatives, Corros. Sci., 1999, 41, no. 10, 1911-1919. doi: 10.1016/S0010-938X(99)00027-X

98. J. Bartley, N. Huynh, S.E. Bottle, H. Flitt, T. Notoya and D.P. Schweinsberg, Computer simulation of the corrosion inhibition of copper in acidic solution by alkyl esters of 5 carboxybenzotriazole, Corros. Sci., 2003, 45, no. 1, 81-96. doi: 10.1016/S0010938X(02)00051-3

99. E.E. Oguzie, S.G. Wang, Y. Li and F.H. Wang, Influence of iron microstructure on corrosion inhibitor performance in acidic media, J. Phys. Chem. C, 2009, 113, no. 19, 8420-8429. doi: 10.1021/jp9015257

100. A. Kadhim, A.K. Al-Okbi, D.M. Jamil, A. Qussay, A.A. Al-Amiery, T.S. Gaaz, A.A.H. Kadhum, A.B. Mohamad and M.H. Nassir, Experimental and theoretical studies of benzoxazines corrosion inhibitors, Results Phys., 2017, 7, 4013-4019. doi: 10.1016/j.rinp.2017.10.027

101. D. Liu, Y.B. Qiu, Y. Tomoe, K. Bando and X.P. Guo, Interaction of inhibitors with corrosion scale formed on $\mathrm{N} 80$ steel in $\mathrm{CO}_{2}$-saturated $\mathrm{NaCl}$ solution, Mater. Corros., 2011, 62, 1153-1158. doi: $\underline{10.1002 / \mathrm{maco} .201106075}$

102. E. Barmatov, T. Hughes and M. Nagl, NACE Int., 2015, 5893, 1-14.

103. Y.P. Khodyrev, E. Batyeva, E. Badeeva, E. Platova, L. Tiwari and O. Sinyashin, The inhibition action of ammonium salts of $\mathrm{O}, \mathrm{O}^{\prime}$-dialkyldithiophosphoric acid on carbon dioxide corrosion of mild steel, Corros. Sci., 2011, 53, 976-983. doi: 10.1016/j.corsci.2010.11.030

104. A.A. Al-Amiery and L.M. Shaker, Corrosion inhibition of mild steel using novel pyridine derivative in $1 \mathrm{M}$ hydrochloric acid, Koroze Ochr. Mater., 2020, 64, no. 2, 5964. doi: $10.2478 / \mathrm{kom}-2020-0009$

105. A.A. Al-Amiery, A.A.H. Kadhum, A.H.M. Alobaidy, A.B. Mohamad and P.S. Hoon, Novel corrosion inhibitor for mild steel in $\mathrm{HCl}$, Materials, 2014, 7, no. 2, 662-672. doi: 10.3390/ma7020662

106. K.F. Al-Azawi, I.M. Mohammed, S.B. Al-Baghdadi, T.A. Salman, H.A. Issa, A.A. AlAmiery, T.S. Gaaz and A.A.H. Kadhum, Experimental and quantum chemical simulations on the corrosion inhibition of mild steel by 3-((5-(3,5-dinitrophenyl)-1,3,4thiadiazol-2-yl)imino)indolin-2-one, Results Phys., 2018, 9, 278-283. doi: 10.1016/j.rinp.2018.02.055 
107. S. Junaedi, A. Al-Amiery, A. Kadihum, A.H. Kadhum and A. Mohamad, Inhibition Effects of a Synthesized Novel 4-Aminoantipyrine Derivative on the Corrosion of Mild Steel in Hydrochloric Acid Solution together with Quantum Chemical Studies, Int. J. Mol. Sci., 2013, 14, 11915-11928. doi: 10.3390/ijms140611915

108. H.R. Obayes, G.H. Alwan, A.H.MJ. Alobaidy, A.A. Al-Amiery, A.A.H. Kadhum and A.B. Mohamad, Quantum chemical assessment of benzimidazole derivatives as corrosion inhibitors, Chem. Cent. J., 2014, 8, no. 21, 1-8. doi: 10.1186/1752-153X-8-21

109. T.A. Salman, Q.A. Jawad, M.A.M. Hussain, A.A. Al-Amiery, L.M. Shaker, A.A.H. Kadhum and M.S. Takriff, New environmental friendly corrosion inhibitor of mild steel in hydrochloric acid solution: Adsorption and thermal studies, Cogent Eng., 2020, 7, no. 1, 1826077. doi: 10.1080/23311916.2020.1826077

110. K. Tamalmani and H. Husin, Review on Corrosion Inhibitors for Oil and Gas Corrosion Issues, Appl. Sci., 2020, 10, 3389. doi: 10.3390/app10103389

111. A. Mahmood and H. Dawood, A Comprehensive Review of Corrosion and its Inhibition in the Oil and Gas Industry, In Proceedings of the SPE Kuwait Oil and Gas Show and Conference, Mishref, Kuwait, 2015, Society of Petroleum Engineers. doi: 10.2118/175337-MS

112. E. Oguzie, Y. Li, S. Wang and F. Wang, Understanding corrosion inhibition mechanisms - Experimental and theoretical approach, RSC Adv., 2011, 1, no. 5, 866873. doi: $10.1039 / \mathrm{C} 1 \mathrm{RA} 00148 \mathrm{E}$

113. L. Guo, W. Dong and S. Zhang, Theoretical challenges in understanding the inhibition mechanism of copper corrosion in acid media in the presence of three triazole derivatives, $R S C A d v$., 2014, 4, 41956-41967. doi: 10.1039/C4RA04931D

114. L. Guo, C. Qi, X. Zheng, R. Zhang, X. Shen and S. Kaya, Toward understanding the adsorption mechanism of large size organic corrosion inhibitors on an $\mathrm{Fe}(110)$ surface using the DFTB method, $R S C A d v$., 2017, 7, 29042-29050. doi: 10.1039/C7RA04120A 